\title{
Effects of Dietary Cereals on Lipid Contents of Serum and Liver in Growing Chicks
}

\author{
Yoshito Chochi, Koichi Mryahana*, Yuzo Hikami*, \\ Shin HaSEgawa* and Toshio Mizuno* \\ The Graduate School of Science and Technology, \\ Kobe University, Kobe-shi 657 \\ *Faculty of Agriculture, Kobe University, Kobe-shi 657
}

(Received April 25, 1984)

\begin{abstract}
Four experiments were conducted with White Leghorn male chicks to investigate the effects of dietary cereals on the serum and hepatic contents of lipids. 1) In comparison of different cereals in isocaloric diets, total lipid (TL) contents of serum and liver were the highest for chicks fed corn and husked rice diets and the lowest for those fed barley, naked barley and rye diets. An intermediate level was obtained with a wheat diet. 2) A milled naked barley diet was nearly as effective as a whole naked barley diet in lowering the TL and cholesterol contents of the serum and the TL content of the liver. Naked barley bran added to a corn starch diet at a level of $25 \%$ reduced TL and cholesterol contents of the serum, but the liver TL content was not influenced. 3) The addition of naked barley bran to a corn starch diet containing 1\% cholesterol was effective in lowering the serum levels of TL, triglyceride (TG) and cholesterol, but had no effect on the lipid level of the liver. 4) Force-feeding a corn starch diet containing naked barley bran reduced TL and TG levels of the liver as compared with force-feeding a diet without the bran, whereas the levels of TL and TG in the serum were not affected.

Jpn. J. Zootech. Sci., 55 (12): 964-972, 1984
\end{abstract}

A number of studies have been made on the effects of dietary cereals on the lipid contents of the plasma and liver in laying hens and Japanese quail, but the results sometimes conflict. JENSEN et al. ${ }^{1}$ compared liver fat accumulation in hens fed isocaloric diets containing different cereal grains and obtained the result that the liver fat content of hens fed diets containing wheat, barley, oats and rye was less than that of hens fed diets containing corn and sorghum. PATEL et al. ${ }^{2)}$ reported that hens fed diets containing wheat and rye showed a lipid content of the liver significantly lower than those fed a corn diet, and ROGEL and VOHRA ${ }^{3)}$ indicated that the addition of oat bran and hull to a semipurified diet containing $0.5 \%$ cholesterol was effective in owering the liver lipid content of Japanese quail. MaUrice and JENSEN ${ }^{4-6)}$ reported that feeding a wheat diet reduced the lipid contents of the plasma and liver in Japanese quail, as compared with feeding a corn diet. On the contrary, KIM et al. ${ }^{7}$ ) and HAGHIGHI-RAD and PoLIN ${ }^{8)}$ found no significant difference in the liver lipid content between hens fed diets containing corn and wheat.

The effects of dietary cereals on the lipid contents of the plasma and liver in growing chicks have received limited investigation. JENSEN et al. ${ }^{1)}$ reported that the liver 


\section{Dietary Cereals on Liver Lipid Content}

lipid content in chicks fed diets containing corn and wheat showed no difference attributable to the source of dietary cereal, and BuRGER et al..$^{9)}$ indicated that the plasma triglyceride content in chicks fed the barley diet was elevated significantly over those fed the corn diet.

The present study was conducted to evaluate the effects of cereals in isocaloric diets on the levels of serum and hepatic lipids in growing chicks.

\section{Materials and Methods}

Male White Leghorn chicks were used for all experiments. The compositions of diets are shown in Tables 1 and 2. Crude protein in each diet was measured in our laboratory and metabolizable energy was estimated on the basis of the following metabolizable energy values; ( $\mathrm{kcal} / \mathrm{g}$ ) 3.83 for isolated soybean protein ${ }^{10)}, 3.50$ and 3.43 for corn starch and milled naked barley, calculated from values of their digestible nutrients $^{11)}$ and for other ingredients values listed in tables of feed composition ${ }^{12)}$ were used. The diets were available to chicks at all times, except in experiment 4 . After

Table 1. Composition of diets (\%)

\begin{tabular}{|c|c|c|c|c|c|c|}
\hline Ingredients & $\begin{array}{c}\text { I } \\
\text { Corn } \\
\text { diet }\end{array}$ & $\begin{array}{c}\text { II } \\
\text { Husked } \\
\text { rice } \\
\text { diet }\end{array}$ & $\begin{array}{c}\text { III } \\
\text { Barley } \\
\text { diet }\end{array}$ & $\begin{array}{c}\text { IV } \\
\text { Naked } \\
\text { barley } \\
\text { diet }\end{array}$ & $\begin{array}{c}\mathrm{V} \\
\text { Wheat } \\
\text { diet }\end{array}$ & $\begin{array}{c}\text { VI } \\
\text { Rye } \\
\text { diet }\end{array}$ \\
\hline Corn & 65.65 & - & - & - & - & - \\
\hline Husked rice & - & 64.65 & - & - & - & - \\
\hline Barley & - & - & 74.65 & - & - & - \\
\hline Naked barley & - & - & - & 69.65 & - & - \\
\hline Wheat & - & - & - & - & 64.65 & - \\
\hline Rye & - & - & - & - & - & 69.65 \\
\hline Soybean meal & 30.00 & 31.00 & 12.00 & 19.00 & 29.00 & 21.00 \\
\hline Isolated Soybean protein ${ }^{1)}$ & - & - & 7.00 & 5.00 & - & 4.00 \\
\hline Soybean oil & - & - & 2.00 & 2.00 & 2.00 & 1.00 \\
\hline DL-Methionine & 0.20 & 0.20 & 0.20 & 0.20 & 0.20 & 0.20 \\
\hline L-Lysine & 0.10 & 0.10 & 0.10 & 0.10 & 0.10 & 0. 10 \\
\hline Calcium phosphate, dibasic & 2.00 & 2.00 & 2.00 & 2.00 & 2.00 & 2. 00 \\
\hline Calcium carbonate & 1.50 & 1.50 & 1.50 & 1.50 & 1.50 & 1.50 \\
\hline Sodium chloride & 0.40 & 0.40 & 0.40 & 0.40 & 0.40 & 0.40 \\
\hline Vitamin mixture & 0.10 & 0.10 & 0.10 & 0.10 & 0.10 & 0.10 \\
\hline Trace mineral mixture ${ }^{3)}$ & 0.05 & 0.05 & 0.05 & 0.05 & 0.05 & 0.05 \\
\hline Total & 100 & 100 & 100 & 100 & 100 & 100 \\
\hline Crude protein, \% & 20.20 & 20.02 & 19.98 & 19.97 & 20.24 & 20.07 \\
\hline $\begin{array}{c}\text { Metabolijable energy, } \\
\mathrm{kcal} / \mathrm{kg}\end{array}$ & 2,835 & 2,861 & 2,802 & 2,817 & 2,815 & 2,777 \\
\hline
\end{tabular}

1) Isolated soybean protein was obtained from Fuji Oil Co., Ltd. Crude protein tontent was $83.07 \%$. 2) per $\mathrm{kg}$ of diet: (in $\mathrm{mg}$ ) riboflavin 5.0 , njacin 25.0 , calcium pantothenate 10.0 , pyridoxine- $\mathrm{HCl} 5.0$, folic acid 0.1 , vitamin $\mathrm{B}_{12} 0.02$, choline chloride 430 , retinyl palmitate $10,000 \mathrm{IU}$, cholecalciferol 1,000 ICU premixed in glucose. 3) per kg of diet: (in mg) $\mathrm{MnO}_{2}$ $60, \mathrm{ZnCO}_{2} 40, \mathrm{FeSO}_{4} \cdot 7 \mathrm{H}_{2} \mathrm{O} 125$, $\mathrm{KI} 1.5$ premixed in $\mathrm{CaCO}_{3}$. 
Chochi, Miyahana, Hikami, Hasegawa and Mizuno

Table 2. Composition of diets (continued) (\%)

\begin{tabular}{|c|c|c|c|c|c|c|}
\hline Ingredients & $\begin{array}{c}\text { VII } \\
\text { Corn } \\
\text { starch } \\
\text { diet }\end{array}$ & $\begin{array}{c}\text { VIII } \\
\text { Corn } \\
\text { starch- } \\
\text { bran } \\
\text { diet }\end{array}$ & $\begin{array}{c}\text { IX } \\
\text { Milled } \\
\text { naked } \\
\text { barley } \\
\text { diet }\end{array}$ & $\begin{array}{c}\mathrm{X} \\
\text { Corn } \\
\text { starch- } \\
\text { cholesterol } \\
\text { diet }\end{array}$ & $\begin{array}{c}\text { XI } \\
\text { Corn } \\
\text { starch- } \\
\text { cholesterol- } \\
\text { bran } \\
\text { diet }\end{array}$ & $\begin{array}{c}\text { XII } \\
\text { Corn } \\
\text { starch- } \\
\text { bran } \\
\text { diet }\end{array}$ \\
\hline Corn starch & 47.7 & 35.1 & 8.1 & 47.7 & 36.6 & 47.0 \\
\hline Naked barley bran & - & 25.0 & 一 & - & 20.0 & 15.0 \\
\hline Milled naked barley & - & - & 46.0 & - & - & - \\
\hline Soybean meal & 43.5 & 26.0 & 36.0 & 43.5 & 34.3 & 19.7 \\
\hline Isolated soybean protein & - & 5.0 & - & - & 1.1 & 9.5 \\
\hline Soybean oil & 2.0 & 2.0 & 2.0 & 2.0 & 1.1 & 1.0 \\
\hline Cellulose & 1.0 & 1.0 & 2.0 & - & - & 2.0 \\
\hline Cholesterol & - & - & - & 1.0 & 1.0 & - \\
\hline DL-Methionine & 0.2 & 0.2 & 0.2 & 0.2 & 0.2 & 0.2 \\
\hline L-Lysine & - & 0.1 & 0.1 & 一 & 0.1 & 0.1 \\
\hline Calcium phosphate, dibasic & 2.0 & 2.0 & 2.0 & 2.0 & 2.0 & 2.0 \\
\hline Calcium carbonate & 1.5 & 1.5 & 1.5 & 1.5 & 1.5 & 1.5 \\
\hline Sodium chloride & 0.4 & 0.4 & 0.4 & 0.4 & 0.4 & 0.4 \\
\hline Vitamin mixture & 1.5 & 1.5 & 1.5 & 1.5 & 1.5 & 1.5 \\
\hline Trace mineral mixture $\left.{ }^{2}\right)$ & 0.1 & 0.1 & 0.1 & 0.1 & 0.1 & 0.1 \\
\hline Choline chloride & 0.1 & 0.1 & 0.1 & 0.1 & 0.1 & 0.1 \\
\hline Total & 100 & 100 & 100 & 100 & 100 & 100 \\
\hline Crude protein, $\%$ & 20.80 & 20.87 & 20.94 & 20.79 & 20.73 & 19.90 \\
\hline $\begin{array}{c}\text { Metabolizable energy, } \\
\mathrm{kcal} / \mathrm{kg}\end{array}$ & 2,923 & 2,765 & 2,929 & 2,960 & 2,688 & 2,899 \\
\hline
\end{tabular}

1) per $\mathrm{kg}$ of diet: (in $\mathrm{mg}$ ) thiamine- $\mathrm{HCl} 6.0$, riboflavin 9.0 , niacin 50.0 , calcium pantotnenate 20. 0 , pyridoxine- $\mathrm{HCl} 8.0$, biotin 0.3 , folic acid 2.0, menadione sodium bisulfite 2.0 , inositol 1,000 , vitamin $B_{12} 0.02$, retinyl palmitate $25,000 \mathrm{IU}$, cholecalciferol 1, $200 \mathrm{ICU}, \mathrm{DL}$ - $\alpha$-tocopherol acetate 17.6 IU premixed in glucose. 2) per $\mathrm{kg}$ of diet: (in mg) $\mathrm{MnO}_{2} 120, \mathrm{ZnCO}_{3} 80, \mathrm{FeSO}_{4}$. $7 \mathrm{H}_{2} \mathrm{O} 250$, $\mathrm{KI} 3$ premixed in $\mathrm{CaCO}_{\mathrm{s}}$.

2 hours of fasting venous blood was withdrawn and then the chicks were killed. Livers were immediately excised and weighed.

In experiment 1, day-old chicks divided into 6 groups were given the diets IVI shown in Table 1 . At 20 days of age the chicks were taken for determinations. In experiment 2, day-old chicks were allocated into 5 groups. Two groups were fed the corn and naked barley diets (I, IV) and the others were given the corn starch diet with or without naked barley bran (VII, VII) and the milled naked barley diet (X) shown in Table 2. Bran and milled naked barley, yields of which were 35 and $65 \%$ respectively, were added to the diets at levels equivalent to the amounts supplied by whole naked barley contained in the naked barley diet (IV) in Table 1. At 20 days of age the chicks were taken for determinations. In experiment 3, day-old chicks were maintained on the corn starch diet (VI) untill 14 days of age and then divided into 3 groups. One group was continuously fed the corn starch diet and the others were given the cholesterol-supplemented diet with or without naked barley 
bran (X, XI). At 22 days of age the chicks were taken for determinations. In experiment 4, chicks were freely given the corn starch diet (VI) from day-old until 12 days of age and then divided into 3 groups. One group served as ad libitum-fed control by being freely fed the corn starch diet (VII) and the others were force-fed the corn starch and corn starch-bran diets (VII, XII) for 14 days, respectively. An amount of diet equivalent to $130 \%$ of the ad libitum intake was allocated into 3 parts, which were force-fed daily at 10.00, 14.00 and 18.00 hours. The diet was blended with water ( 1 part diet +1.5 parts water) and introduced into the crop by a $50 \mathrm{ml}$ plastic syringe through a $5 \mathrm{~mm}$ diameter tube. All the chicks in 3 groups were taken for determinations at 27 days of age.

The determinations of total lipid (TL), triglyceride (TG) and total cholesterol in serum were carried out by the methods of BRAGDON ${ }^{19)}$, FLETCHER ${ }^{14)}$ and $Z_{\text {AK }}$ et al. ${ }^{15}$, respectively. TL, TG and cholesterol in the liver were determined by the same methods as in serum after being extracted from the liver according to the method of Folch et al. $^{16)}$.

\section{Results and Discussion}

Experiment 1. The effects of dietary cereals on lipid contents of the serum and liver in chicks are shown in Table 3. No significant difference in growth of chicks existed among diets containing corn, husked rice, barley, naked barley and wheat. The rye diet, as compared with diets containing other cereals, produced relatively poor weight gain, this being in agreement with the result obtained by FERNANDEz et al. ${ }^{17)}$, who reported the undesirable effect of rye on growth of chicks. Liver weights in chicks fed diets containing barley, naked barley and rye were significantly less

Table 3. Effects of cereals on lipid contents of serum and liver in chicks

\begin{tabular}{|c|c|c|c|c|c|c|}
\hline & $\begin{array}{c}I \\
\text { Corn } \\
\text { diet }\end{array}$ & $\begin{array}{l}\text { II } \\
\text { Husked } \\
\text { rice } \\
\text { diet }\end{array}$ & $\begin{array}{c}\text { III } \\
\text { Barley } \\
\text { diet }\end{array}$ & $\begin{array}{c}\text { IV } \\
\text { Naked } \\
\text { barley } \\
\text { diet }\end{array}$ & $\begin{array}{c}\mathrm{V} \\
\text { Wheat } \\
\text { diet }\end{array}$ & $\begin{array}{c}\text { VI } \\
\text { Rye } \\
\text { diet }\end{array}$ \\
\hline Body weight, $\mathrm{g}$ & $182 \pm 2^{a_{11}}$ & $178 \pm 3^{\text {a }}$ & $182 \pm 1^{\mathrm{a}}$ & $181 \pm 2^{\mathrm{a}}$ & $177 \pm 3^{\mathrm{a}}$ & $167 \pm 2^{\mathrm{b}}$ \\
\hline Liver weight, $\mathbf{g}$ & $5.2 \pm 0.3^{a}$ & $5.3 \pm 0.2^{\mathrm{a}}$ & $4.3 \pm 0.1^{b c}$ & $4.2 \pm 0.1^{b}$ & $4.7 \pm 0.1^{c}$ & $4.1 \pm 0.1^{b}$ \\
\hline $\begin{array}{l}\text { Feed consumption, } \\
\text { g/bird } / 19 \text { days }\end{array}$ & 313 & 304 & 330 & 328 & 328 & 322 \\
\hline \multicolumn{7}{|l|}{ Serum, $\mathrm{mg} / 100 \mathrm{~m} l$} \\
\hline Total lipid & $704 \pm 30^{8}$ & $694 \pm 34^{\mathrm{a}}$ & $466 \pm 25^{b c}$ & $449 \pm 19^{b}$ & $520 \pm 16^{c}$ & $339 \pm 22^{b}$ \\
\hline Triglyceride & $188 \pm 8^{\mathrm{a}}$ & $166 \pm 8^{a b}$ & $163 \pm 6^{a j}$ & $157 \pm 5^{b}$ & $180 \pm 6^{2}$ & $166 \pm 6^{a b}$ \\
\hline Total cholesterol & $212 \pm 5^{a}$ & $197 \pm 10^{2}$ & $160 \pm 5^{b}$ & $146 \pm 11^{b}$ & $161 \pm 4^{b}$ & $141 \pm 6^{\circ}$ \\
\hline \multicolumn{7}{|l|}{ Liver, $\mathrm{mg} / \mathrm{g}$ of liver } \\
\hline Total lipid & $42.9 \pm 1.6^{a}$ & $42.9 \pm 1.4^{\mathrm{a}}$ & $34.2 \pm 1.3^{b c}$ & $30.0 \pm 1.8^{\mathrm{b}}$ & $36.6 \pm 0.6^{\mathrm{c}}$ & $33.5 \pm 1.1^{\mathrm{ab}}$ \\
\hline Triglyceride & $6.6 \pm 0.6^{a}$ & $5.9 \pm 0.1^{a}$ & $5.3 \pm 0.4^{\mathrm{a}}$ & $6.3 \pm 0.3^{a}$ & $6.4 \pm 0.4^{a}$ & $6.4 \pm 0.3^{\mathrm{a}}$ \\
\hline Total cholesterol & $5.0 \pm 0.2^{\mathrm{a}}$ & $5.2 \pm 0.1^{a}$ & $5.1 \pm 0.2^{\mathrm{a}}$ & $5.3 \pm 0.2^{\mathrm{ab}}$ & $5.2 \pm 0.1^{a}$ & $5.7 \pm 0.1^{b}$ \\
\hline
\end{tabular}

1) Mean \pm S.E. for 5 chicks. a, b, c: values with different superscript letters in the same horizontal column are significantly different $(P<0.05)$. 
than those in chicks fed the corn and husked rice diets.

Serum TL content was altered in a parallel fashion with liver TL content when chicks were fed diets containing the cereals tested. TL contents of the serum and liver were the highest for chicks fed the corn and husked rice diets and the lowest for those fed the barley, naked barley and rye diets. An intermediate level was obtained with the wheat diet. JENSEN et al. ${ }^{1}$, using laying hens, compared several cereal grains to determine their effects on liver fat content and found that barley, oats and rye significantly reduced liver fat content as compared with corn and sorghum, the response to wheat being moderate. The result obtained in the present experiment with growing chicks is in good agreement with that reported by JENSEN et al. JENSEN et al. ${ }^{1}$, however, indicated that no lowering effect of wheat on liver fat content was observed in their experiment with growing broiler chicks. A similar result was obtained also in our experiment with broiler chicks (unpublished observation). In the present experiment White Leghorn chicks were used. There may be, therefore, a species-specific difference between chicks in the response of their serum and liver fats to dietary cereals.

The serum TG content of chicks fed the naked barley diet was significantly less than that of chicks fed that corn and wheat diets and the intermediate response was obtained with the husked rice, barley and rye diets. No significant difference in liver TG content was observed among chicks fed diets containing the cereals tested. There is little work on the effect of dietary cereals on serum and liver TG contents in birds. BURGER et al. ${ }^{9)}$ reported that the plasma TG content in chicks fed barley was raised significantly over those fed corn, in contrast to the result obtained in this experiment.

Serum cholesterol level was significantly lower for chicks fed the barley, naked barley, wheat and rye diets than for those fed the corn and husked rice diets. This result shows close agreement with the reports of FISHER and GRIMINGER ${ }^{18)}$ and QURESHI et al. ${ }^{19)}$, who indicated that feeding diets containing wheat, barley, oats and rye significantly reduced the cholesterol content of plasma in chicks, in comparison with feeding a diet with corn. No significant difference in the cholesterol content of the liver was observed among chicks fed diets containing the cereals tested, except for those fed the rye diet.

All subsequent experiments were restricted to naked barley or naked barley fractions as the dietary variables, because this cereal was highly effective in lowering the lipid contents of the serum and liver.

Experiment 2. Whole naked barley was compared with a quantity of naked barley bran equivalent to the amount supplied by whole naked barley and with an equivalent amount of milled naked barley (Table 4). No significant difference existed between chicks fed the corn and corn starch diets in body weight, liver weight and serum levels of TL and cholesterol, although chicks fed the corn starch diet showed slightly higher levels of liver TL and cholesterol. The naked barley diet significantly reduced the TL and cholesterol contents of the serum and the TL content of the liver 
Dietary Cereals on Liver Lipid Content

Table 4. Effects of naked barley fractions on lipid contents of serum and liver in chicks

\begin{tabular}{|c|c|c|c|c|c|}
\hline & $\begin{array}{c}I \\
\text { Corn } \\
\text { diet }\end{array}$ & $\begin{array}{c}\text { IV } \\
\text { Naked } \\
\text { barley } \\
\text { diet }\end{array}$ & $\begin{array}{c}\text { VII } \\
\text { Corn } \\
\text { starch } \\
\text { diet }\end{array}$ & $\begin{array}{c}\text { VIII } \\
\text { Corn } \\
\text { starch- } \\
\text { bran } \\
\text { diet }\end{array}$ & $\begin{array}{l}\text { IX } \\
\text { Milled } \\
\text { naked } \\
\text { barley } \\
\text { diet }\end{array}$ \\
\hline Body weight, $\mathrm{g}$ & $177 \pm 1.3^{\mathrm{ab} 1\}}$ & $180 \pm 0.4^{\mathrm{b}}$ & $172 \pm 0.4^{2}$ & $179 \pm 1.3^{a b}$ & $172 \pm 0.9^{2}$ \\
\hline Liver weight, $\mathbf{g}$ & $4.9 \pm 0.2^{\mathrm{a}}$ & $4.4 \pm 0.1^{\mathrm{ab}}$ & $4.6 \pm 0.1^{\mathrm{ab}}$ & $4.2 \pm 0 . I^{b}$ & $4.5 \pm 0.1^{\mathrm{ab}}$ \\
\hline $\begin{array}{l}\text { Feed consumption } \\
\qquad \mathrm{g} / \mathrm{bird} / 19 \text { days }\end{array}$ & 357 & 357 & 326 & 334 & 364 \\
\hline \multicolumn{6}{|l|}{ Serum, $\mathrm{mg} / 100 \mathrm{~m} l$} \\
\hline Total lipid & $658 \pm 17^{\mathrm{a}}$ & $559 \pm 14^{b c}$ & $663 \pm 15^{a}$ & $585 \pm 16^{\mathbf{b}}$ & $523 \pm 14^{c}$ \\
\hline Total cholesterol & $210 \pm 7^{\mathrm{a}}$ & $176 \pm 5^{b}$ & $208 \pm 7^{a}$ & $175 \pm 6^{b}$ & $176 \pm 5^{b}$ \\
\hline \multicolumn{6}{|l|}{ Liver, $\mathrm{mg} / \mathrm{g}$ of liver } \\
\hline Total lipid & $35.9 \pm 0.2^{\mathrm{a}}$ & $32.8 \pm 0.8^{b}$ & $41.6 \pm 1.9^{c}$ & $37.9 \pm 0.6^{\mathrm{C}}$ & $32.4 \pm 1.3^{b}$ \\
\hline Total cholesterol & $4.9 \pm 0.1^{\mathrm{a}}$ & $5.0 \pm 0.1^{\mathrm{a}}$ & $5.7 \pm 0.2^{\mathrm{b}}$ & $5.8 \pm 0.2^{\mathrm{b}}$ & $4.9 \pm 0.2^{\mathrm{a}}$ \\
\hline
\end{tabular}

1) Mean \pm S. E. for 5 chicks. a, b, c: values with different superscript letters in the same horizontal column are significantly different $(P<0.05)$.

in comparison with the corn and corn starch diets, this being similar to the result obtained in experiment 1. The milled naked barley diet was nearly as effective as the naked barley diet in lowering the TL and cholesterol contents of the serum and the TL content of the liver. Naked barley bran, which was added to the corn starch diet at a level of $25 \%$, also reduced the contents of serum TL and cholesterol to levels close to the values observed in chicks fed the naked barley diet, but the TL content of the liver was not influenced. Although the reason why naked barley bran has no effect on the TL content of the liver is not clear, it is inferred that the lipid-lowering effect of the bran may appear with difficulty in the liver, because the bran is added to the corn starch diet, which has a tendency to raise the liver lipid content more than does the corn diet. MAURICE and JENSEN ${ }^{20)}$ reported that wheat bran significantly reduced the plasma and hepatic lipids of hens as compared with corn. CHER$\mathrm{RY}$ and JoNES ${ }^{21}$, on the contrary, indicated no lowering effec: of wheat bran on lipid levels of the serum and liver in hens.

From the results obtained in this experiment the lipid-lowering activity of naked barley is thought to exist in both bran and milled naked barley.

Experiment 3. The effects of naked barley bran on the lipid contents of the serum and liver in chicks fed the corn starch diet supplemented with cholesterol were studied (Table 5). Serum and hepatic levels of lipids, except for liver TG, were significantly higher in chicks fed the cholesterol-supplemented diet than in those fed the diet without cholesterol. Sim and $\mathrm{BRAGG}^{22)}$ reported that a diet containing cholesterol elevated the levels of serum and hepatic TL in hens, as compared with a control diet. The addition of naked barley bran to the corn starch diet containing cholesterol reduced the levels of TL, TG and cholesterol in serum to approximately 72,79 and $69 \%$, respectively, of the values obtained when the bran was not added. 
Table 5. Effects of naked barley bran on lipid contents of serum and liver in chicks fed the diet containing $1 \%$ cholesterol

\begin{tabular}{|c|c|c|c|}
\hline & $\begin{array}{c}\text { VII } \\
\text { Corn starch } \\
\text { diet }\end{array}$ & $\begin{array}{c}\mathrm{X} \\
\text { Corn starch- } \\
\begin{array}{c}\text { cholesterol } \\
\text { diet }\end{array}\end{array}$ & $\begin{array}{l}\text { XI } \\
\text { Corn starch- } \\
\text { cholesterol- } \\
\text { dran diet }\end{array}$ \\
\hline Body weigh, $\mathrm{g}$ & $190 \pm 1^{\text {a1) }}$ & $181 \pm 4^{b}$ & $182 \pm 3^{\mathrm{ab}}$ \\
\hline Liver weight, $g$ & 4. $7 \pm 0.5^{a}$ & $5.1 \pm 0.2^{\mathrm{a}}$ & $4.7 \pm 0.2^{\mathrm{a}}$ \\
\hline $\begin{array}{l}\text { Feed consumption, } \\
\text { g/bird } / 21 \text {, days }\end{array}$ & 322 & 315 & 328 \\
\hline \multicolumn{4}{|l|}{ Serum, $\mathrm{mg} / 100 \mathrm{~m} l$} \\
\hline Total lipid & $549 \pm 18^{a}$ & $1055 \pm 21^{b}$ & $760 \pm 19$ \\
\hline Triglyceride & $76 \pm 3^{a}$ & $104 \pm 3^{b}$ & $82 \pm 5^{a}$ \\
\hline Total cholesterol & $183 \pm 12^{a}$ & $449 \pm 31^{b}$ & $308 \pm 10^{c}$ \\
\hline \multicolumn{4}{|l|}{ Liver, $\mathrm{mg} / \mathrm{g}$ of liver } \\
\hline Total lipid & $37.5 \pm 0.4^{2}$ & $80.4 \pm 1.2^{b}$ & $78.4 \pm 0.8^{b}$ \\
\hline Triglyceride & $6.5 \pm 0.5^{\mathrm{a}}$ & $4.8 \pm 0.3^{b}$ & $5.0 \pm 0.1^{b}$ \\
\hline Total cholesterol & $5.9 \pm 0.5^{\mathrm{a}}$ & $21.8 \pm 0.9^{b}$ & $29.0 \pm 2.4^{b}$ \\
\hline
\end{tabular}

1) Mean \pm S. E. for 5 chicks. a, b, c: values with different superscript in the same horizontal column are significantly different $(P<0.05)$.

In the case of the corn starch diet without cholesterol, serum TL and cholesterol levels observed when the bran was added to the diet were approximately 88 and $84 \%$, respectively, of the values in the control group (Table 4). Serum lipid is thought, therefore, to respond to the lipid-lowering activity of bran more effectively when the bran is added to the cholesterol-supplemented diet than when the bran is added to the diet without cholesterol. Hepatic levels of TL, TG and cholesterol, on the contrary, were not influenced by adding the bran to the cholesterol-supplemented diet. This result is similar to the finding in experiment 2 that when added to the corn starch diet, naked barley bran reduced serum lipid content, but had no effect on liver lipid content. ROGEL and VOHRA ${ }^{3)}$ indicated that the addition of oat bran and hull to a diet containing cholesterol reduced the level of TL in the liver of Japanese quail, although serum cholesterol was not affected, this being in contrast to the observation in this experiment.

Experiment 4. The effects of naked barley bran on lipid contents of the serum and liver in force-fed chicks were studied (Table 6). Force-feeding the corn starch diet markedly raised body weight, liver weight and TL and TG contents of the serum and liver, as compared with ad libitum-feeding the diet, whereas the increase in serum cholesterol was slight and liver cholesterol was adversely reduced. This result is in good agreement with the report presented by NIR and SHAPIRA ${ }^{23)}$, who indicated in their experiment with growing chicks that force-feeding caused a slight but not significant increase in plasma cholesterol and a slight decrease in liver cholesterol as opposed to a marked increase in plasma TG and liver lipid.

Force-feeding the corn starch diet containing naked barey bran significantly re- 


\section{Dietary Cereals on Liver Lipid Content}

Table 6. Effects of naked barley bran on lipid contents of serum and liver in force-fed chicks

\begin{tabular}{|c|c|c|c|}
\hline & \multirow{2}{*}{ 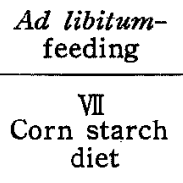 } & \multicolumn{2}{|c|}{ Force-feeding } \\
\hline & & $\begin{array}{c}\text { VII } \\
\text { Corn starch } \\
\text { diet }\end{array}$ & $\begin{array}{c}\text { XII } \\
\text { Corn starch- } \\
\text { bran diet }\end{array}$ \\
\hline Body weight, $\mathrm{g}$ & $281 \pm 3^{\mathrm{a} 13}$ & $339 \pm 4^{b}$ & $344 \pm 3^{b}$ \\
\hline Liver weight, $\mathrm{g}$ & $7.1 \pm 0.3^{\mathrm{a}}$ & $11.2 \pm 0.4^{b}$ & $10.7 \pm 0.2^{b}$ \\
\hline \multicolumn{4}{|l|}{ Serum, $\quad \mathrm{mg} / 100 \mathrm{~m} l$} \\
\hline Total lipid & $636 \pm 16^{a}$ & $895 \pm 20^{6}$ & $858 \pm 25^{b}$ \\
\hline Triglyceride & $69 \pm 6^{\mathrm{a}}$ & $159 \pm 17^{b}$ & $187 \pm 4^{b}$ \\
\hline Total cholesterol & $243 \pm 7^{a}$ & $270 \pm 6^{b}$ & $251 \pm 3^{a b}$ \\
\hline \multicolumn{4}{|l|}{ Liver, $\mathrm{mg} / \mathrm{g}$ of liver } \\
\hline Total lipid & $42.1 \pm 0.6^{\mathrm{a}}$ & $62.3 \pm 2.4^{\mathrm{b}}$ & $49.7 \pm 2.2^{c}$ \\
\hline Triglyceride & $2.4 \pm 0.2^{\mathrm{a}}$ & $11.1 \pm 0.9^{\mathrm{b}}$ & $7.5 \pm 1.2^{c}$ \\
\hline Total cholesterol & $6.0 \pm 0.1^{\mathrm{a}}$ & $4.9 \pm 0.1^{b}$ & $4.9 \pm 0.03^{b}$ \\
\hline
\end{tabular}

1) Mean \pm S. E. for 5 chicks. a, b, c: values with different superscript letters in the same horizontal column are significantly different $(P<0.05)$.

duced the levels of hepatic TL and TG in comparison with force-feeding the diet without bran, whereas serum TL and TG levels as well as cholesterol levels of serum and liver were not affected. This result contrasts with that observed when chicks were ad libitum fed the corn starch diet with or without bran (Table 4). These results suggest, therefore, that the lipid-lowering effect of bran may appear more effectively either in serum or in liver according to the pattern of food intake, such as ad libitum-feeding and force-feeding, although the mechanism of such regulation is not clear. Аківа and Matsumoto ${ }^{24)}$ determined the levels of plasma and hepatic lipid in chicks which were force-fed diets supplemented with or without 6 types of dietary fibers in which cellulose and rice hull NDF (neutral detergent fiber) were involved. They reported that the cellulose diet reduced the lipid contents of both plasma and liver and that the rice hull NDF diet lowered liver lipid content, but had no effect on plasma lipid content. The result reported by АківA and Maтsumoto on the effect of force-feeding of the rice hull NDF diet is similar to that observed in chicks forcefed the corn starch diet containing naked barley bran in this study.

From the results obtained in the present studies, naked barley and its fractions appear to have a high lipid-reducing activity. Identification of the active components in naked barley that are responsible for the lipid-reducing effect and the mechanism by which such materials effect the changes in lipid contents of the serum and liver are currently being studied in our laboratory.

\section{References}

1) Jensen, L. S., C. H. Cheng and R. D. Wyatt, Poultry Sci., 55: 700-709. 1976.

2) Patel, M. B., J. McGinnis and M. H. Pubols, Poultry Sci., 60: 631-636. 1981.

3) Rogel, A. M. and P. Vohra, Poultry Sci., 62: 1045-1053. 1983. 
4) Maurice, D. V: and L. S. Jensen, Poultry Sci., 56: 1353.1977.

5) Maurice, D. V. and L. S. Jensen, Br. Poult. Sci,, 19: 199-205. 1978.

6) Maurice, D. V. and L. S. Jensen, J. Nutr., 109: 872-882. 1979.

7) Kim, S. M., M. B. Patel, S. J. Reddy and J. McGinnis, Poultry Sci., 55: 520-530. 1976.

8) HaGhighi-Rad, F. and D. Polin, Poultry Sci., 61: 2075-2082. 1982.

9) Burger, W. C., A. A. Qureshi, N. Prentice and C.E. Elson, Lipids, 17: 956-963. 1982.

10) Brambila, S. and F. W. Hill, J. Nutr., 88: 84-92. 1966.

11) TAZAKI, I., in Chikusan Dai-Jiten. (TAZaKI, I., ed.) 478. Yokendo Ltd. Tokyo. 1980. (in Japanese).

12) Standard Tables of Feed Composition in Japan. (Edited by National Research Council of Agriculture, Forestry and Fishery) 76-85. Central Association of Livestock Industry. Tokyo. 1975.

13) Bragdon, J. H., in Lipids and the Steroid Hormones in Clinical Medicine. (Sunderman, F. W. and F. W. Sunderman eds.) 9-15. Lippincott. Philadelphia and Montreal. 1960.

14) Fletcher, M. J., Clin. Chim. Acta, 22: 393-397. 1968.

15) Zak, B., R. C. Dickenman, E. G. White, H. Burnett and P. J. Cherney, Amer. J. Clin. Pathol., 24: 1307-1315. 1954.

16) Folch, J., M. Lees and G. H. Sloanestanley, J. Biol. Chem., 226: 497-509. 1957.

17) Fernandez, R., E. Lucas and J. McGinnis, Poulyry Sci., 52: 2252-2259. 1973.

18) Fisher, H. and P. Griminger, Proc. Soc. Exp. Biol. Med., 126: 108-111. 1967.

19) Oureshi, A. A., W. C. Burger, N. Prentice, H. R. Bird and M. L. Sunde, J. Nutr., 110: 388-393. 1980.

20) Maurice, D. V. and L.S. Jensen, Poultry Sci., 57: 989-997. 1978.

21) Cherry, J.A. and D.E. Jones, Poultry Sci., 61: 1873-1878. 1982.

22) Sim, J.S. and D. B. BragG, Poultry Sci., 57: 466-472. 1978.

23) Nir, I. and N. Shapira, Br. J. Nutr., 32: 229-239. 1974.

24) Aкiвa, Y. and T. Matsumoto, J. Nutr., 110: 1112-1121. 1980.

\title{
鷄ヒナの血清および肝藏脂質量に及ぼす穀類給与の影響
}

\author{
帖地孝人・宮花浩一*.水上雄三* \\ 長谷川 信*・水野利雄*
}

神戸大学大学院自然科学研究科, 神戸市 657

*神戸大学農学部, 神戸市 657

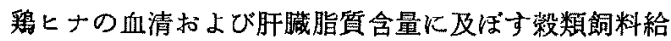
与の影響を検討した．1）同一代謝エネルギーの条件下 で，各種款類飼料を比較した場合，血清格よび肝藏の総 脂質 (TL) 量は，トゥモロコシをたは玄米飼料を給与し た場合に最大で，小考飼料給与がこれに次ぎ，大麦，裸麦 またはライ麦飼料給与の場合が最小であった，2）精白 した裸荄飼料を給与すると，血清のTL拉よびコレステ ロール含量並びに肝䁍の TL 含量は, 全粒裸麦飼料を給 与した場合とほぼ同剭度の值にまで低下した、裸麦ヌカ をトウモロコシ澱粉飼料に $25 \%$ の剖合で添加すると，血 清のTL抽びコレステロール含量は減少するが，肝藏
のTL 含量は影響を受けなかった３）1\%ヌレステロー ルを含むトウ亡ロコシ澱粉飼料に裸麦ヌカを添加した場 合む，血清の TL，トリグリセりド(TG)およびュレス テロール含量は減少したが，肝臟の脂質含量には影響が 認められなかった．4）裸麦ヌカを添加したトウモロコ シ澱粉飼料を，自由掑取時の $130 \%$ 相当量の割合で強制 給与すると，裸麦ヌカ無添加のトゥモロコン溊粉飼料を 強制給与した場合に比べ，䀒䐵の TL および TG 含量 は低下したが，血清の脂質含量には差が諮められながっ た. 日畜会報，55(12)：964-972，1984 